\title{
Hubungan Kadar Timbal Darah dengan Tingkat Inteligensi Anak
}

Dewi Mutiati Ratnasari, Mei Neni Sitaresmi, Nenny Sri Mulyani

Bagian Ilmu Kesehatan Anak Fakultas Kedokteran Universitas Gadjah Mada/RSUP Dr. Sardjito, Yogyakarta

Latar belakang. Timbal telah terbukti neurotoksin. Kadar timbal yang tinggi dalam darah dihubungkan dengan inteligensi yang rendah pada anak, tetapi sampai saat ini belum ada laporan hubungan kadar timbal dalam darah dengan inteligensi anak di Indonesia khususnya Yogyakarta.

Tujuan. Mengetahui hubungan kadar timbal darah dengan tingkat inteligensi anak.

Metode. Penelitian potong lintang terhadap anak di 7 Sekolah Dasar kelas 1 dan 2 Inklusi di Yogyakarta pada bulan Januari 2013. Subyek penelitian diperoleh secara purposive sampling. Kriteria inklusi adalah anak dengan 5 peringkat tertinggi dan 5 peringkat terendah yang bersedia mengikuti penelitian. Kriteria eksklusi adalah anak dengan sindrom Down, hiperaktif, autis, dan adanya gangguan pendengaran. Inteligensi ditentukan berdasarkan Wechsler Intelligence Scale for Children timbal dalam darah diperiksa dengan alat atomic absorption spectrophotometry. Data dianalisis dengan menggunakan uji independent t-test, uji chi-square, dan uji Fisher. Hasil. Didapatkan 80 anak (40 anak dengan inteligensi tinggi dan 40 anak dengan inteligensi rendah) diikutsertakan dalam penelitian ini. Rerata kadar timbal dalam darah anak dengan inteligensi tinggi 4,09 $\mu \mathrm{g} / \mathrm{dL}$ (SB 0,50) lebih rendah dibandingkan dengan rerata kadar timbal dalam darah anak dengan inteligensi rendah 7,08 $\mu \mathrm{g} / \mathrm{dL}$ (SB 0,61, IK95\%: 1,429-4,555). Kadar timbal dalam darah $\geq 5 \mu \mathrm{g} / \mathrm{dL}$ lebih banyak dijumpai pada anak dengan inteligensi rendah dibandingkan dengan anak dengan inteligensi tinggi $(75 \%$ vs $45 \% ; \mathrm{p}=0,006)$. Hasil analisis bivariat faktor luar didapatkan faktor lain yang memengaruhi tingkat inteligensi anak adalah stimulasi, tingkat pendidikan ibu dan sosial ekonomi $(\mathrm{p}=<0,001, \mathrm{p}=0,001$, dan $\mathrm{p}=0,001)$.

Kesimpulan. Anak dengan inteligensi rendah mempunyai kadar timbal darah yang lebih tinggi dibandingkan anak dengan inteligensi tinggi. Sari Pediatri 2016;18(4):265-9

Kata kunci: inteligensi, kadar timbal darah, anak

\section{Association Between Blood Lead Level and Level of Intelligence in Children}

Dewi Mutiati Ratnasari, Mei Neni Sitaresmi, Nenny Sri Mulyani

Background. Lead has been proven as neurotoxin. High blood lead level is associated with low intelligence in children, but until recently there is no report about the relationship between blood lead level and children's intelligence in Indonesia, especially in Yogyakarta. Objective. To determine the relationship between blood lead level of children and the level of intelligence.

Methods. A cross-sectional study of first and second grades children at seven Inclusion Elementary Schools in Yogyakarta was conducted on January 2013. Subjects were obtained by purposive sampling. The inclusion criteria were children with the fifth highest ranking and the fifth lowest ranking who were willing to be involved in research. Exclusion criteria were children with Down syndrome, hyperactivity, autism, and hearing loss. Intelligence levels were determined by the Wechsler Intelligence Scale for Children. The blood lead levels were checked with atomic absorption spectrophotometry. Data were analyzed using independent t-test, Chi-Square and Fisher. Results. Eighty children ( 40 children with high intelligence and 40 children with low intelligence) were included in this study. The mean blood lead level of subjects with high intelligence was $4.09 \mu \mathrm{g} / \mathrm{dL}$ (SB 0.50), lower than that of children with low intelligence $(7.08 \mu \mathrm{g} / \mathrm{dL}$ (SB 0.61, 95\% CI 1.429-4.555)). Blood lead level of $\geq 5 \mu \mathrm{g} / \mathrm{dL}$ was more common in children with low intelligence compared with those with high intelligence ( $75 \%$ vs $45 \%$ respectively; $\mathrm{p}=0.006)$. The results of bivariate analysis of external factors revealed that other factors affecting children's intelligence level were stimulation, the level of maternal education, and socioeconomic status $(\mathrm{p}=<0.001, \mathrm{p}=0.001$ and $\mathrm{p}=0.001$ respectively).

Conclusions. Children with low intelligence level had higher blood lead level than children with high intelligence. Sari Pediatri 2016;18(4):265-9

Keywords: intelligence, blood lead level, children

Alamat korespondensi: Dr. Dewi Mutiati Ratnasari. Bagian Ilmu Kesehatan Anak Fakultas Kedokteran Universitas Gadjah Mada-RSUP Dr. Sardjito. Jl Kesehatan no. 1, Sekip, Yogyakarta 55281. Email: dewi.atmojo@gmail.com 
I nteligensi adalah kemampuan untuk bertindak secara terarah, berpikir secara rasional, dan menghadapi lingkungan secara efektif. Beberapa faktor yang memengaruhi intelektual individu, yaitu genetik, latar belakang sosial ekonomi, kondisi fisik, emosi, lingkungan dan kondisi tertentu. ${ }^{1}$ Di Yogyakarta, belum ada data prevalensi anak dengan tingkat inteligensi rendah (IQ <90), tetapi sebuah disertasi yang dilakukan oleh Gravitiani ${ }^{2}$ menunjukkan bahwa tahun 2008 di Yogyakarta terdapat 29.234 kasus anak mengalami penurunan tingkat inteligensi karena timbal.

Dewasa ini, polusi lingkungan yang buruk, salah satunya timbal, akan memengaruhi inteligensi anak. ${ }^{3}$ Beberapa penelitian melaporkan kadar timbal dalam darah yang $<10 \mu \mathrm{g} / \mathrm{dL}$ berhubungan dengan penurunan tingkat inteligensi anak. ${ }^{4-7}$ Penelitian Canfield ${ }^{8}$ menunjukkan bahwa setiap kenaikan $10 \mu \mathrm{g} / \mathrm{dL}$ timbal dalam darah berhubungan dengan penurunan 4,6 poin IQ ( $\mathrm{p}=0,004)$. Penelitian yang dilakukan di Boston AS menyimpulkan bahwa paparan timbal pada masa anak dapat memprediksi fungsi intelektual pada dewasa muda. Polusi timbal pada anak bisa didapatkan dari timbal dalam bensin atau dari mainan anak yang mengandung timbal. ${ }^{9-12}$ Pengaruh timbal terhadap inteligensi dapat melalui proses apoptosis, gangguan neurotransmitter, gangguan mekanisme regulator intraneuron, gangguan diferensiasi sel glia, dan hambatan terhadap enzim delta aminolevulinic acid yang menyebabkan penurunan sintesis heme dan hipoksia jaringan otak. ${ }^{3,14}$

Di Indonesia, prevalensi kadar timbal dalam darah antara 5-10 $\mu \mathrm{g} / \mathrm{dL}$ adalah $21,8 \%$, antara $10-20 \mu \mathrm{g} / \mathrm{dL}$ $11,2 \%$, dan kadar timbal lebih dari $20 \mu \mathrm{g} / \mathrm{dL}$ sebesar 6,5\%. ${ }^{9}$ Di Jakarta, anak memiliki kadar timbal ratarata $8,6 \mu \mathrm{g} / \mathrm{dL}$ dan 35\% anak memiliki kadar timbal $>10 \mu \mathrm{g} / \mathrm{dL} .{ }^{15}$ Tahun 2001, center for disease control and prevention (CDC) AS menetapkan batas kadar timbal dalam darah anak adalah $10 \mu \mathrm{g} / \mathrm{dL}$, tetapi beberapa penelitian menunjukkan kadar timbal $5 \mu \mathrm{g} / \mathrm{dL}$ pun dapat menimbulkan efek pada tingkat inteligensi anak. ${ }^{16}$

Dampak timbal terhadap kesehatan anak diutamakan karena pusat perkembangan saraf. ${ }^{14}$ Penelitian ini dilakukan untuk mengetahui hubungan tingkat inteligensi anak dengan kadar timbal dalam darah.

\section{Metode}

Penelitian observasional dengan rancang bangun potong lintang dilakukan di tujuh Sekolah Dasar
(SD) di Yogyakarta pada Januari 2013. Subjek adalah anak kelas 1 dan 2 dengan 5 peringkat tertinggi dan 5 peringkat terendah di masing-masing kelas yang bersedia mengikuti penelitian. Anak dengan tingkat inteligensi normal, menderita sindrom Down, epilepsi, hiperaktif, autis dan gangguan pendengaran tidak diikutsertakan dalam penelitian. Subyek penelitian diambil dengan teknik purposive sampling sampai jumlah subjek terpenuhi. Anak-anak yang memenuhi kriteria insklusi dan eksklusi dinilai tingkat inteligensi oleh dua orang psikolog yang tidak mengetahui hasil pemeriksaan kadar timbal darah. Anak diklasifikasikan menjadi anak dengan tingkat inteligensi tinggi dan rendah.

Kadar timbal diperoleh dari $3 \mathrm{ml}$ darah vena, dihitung mempergunakan satuan $\mu \mathrm{g} / \mathrm{dL}$ dengan metode atomic absorption spectophotometry (AAS). Tingkat inteligensi adalah kemampuan seseorang untuk bertindak secara terarah, berpikir secara rasional, dan menghadapi lingkungannya secara efektif, dinyatakan dalam bentuk rasio. ${ }^{17}$ Skor diukur dengan instrumen Weschler intelligence scale of children (WISC) dengan hasil full scale, performance scale dan verbal scale. Anemia jika terdapat penurunan konsentrasi hemoglobin, hematokrit, atau jumlah sel darah merah per millimeter kubik. ${ }^{18}$ Pemeriksaan kadar hemoglobin dengan menggunakan spektofotometer. Berat badan lahir dihitung dari berat badan saat lahir atau 1 jam setelah lahir. ${ }^{19}$ Keterangan didapat dari ibu pasien atau dari buku KMS. Stimulasi yang diberikan orang tua diukur dengan skala HOME (home observation of measurement of environment) untuk anak sekolah dasar, dinilai oleh dua orang psikolog yang berbeda. ${ }^{20}$ Pendidikan ibu dan status ekonomi didapatkan dari wawancara. Status ekonomi adalah penghasilan keluarga produktif yang dinyatakan dalam rupiah per bulan sesuai upah minimum regional kota Yogyakarta tahun 2012. ${ }^{21,22}$

Data dianalisis secara statistik dengan menggunakan program komputer. Karakteristik dasar subjek penelitian dipresentasikan sebagai frekuensi, rerata, dan simpang baku. Perbedaan rerata kadar timbal dalam darah pada anak dengan tingkat inteligensi tinggi dan rendah dibandingkan dengan menggunakan uji independent t-test, sedangkan perbedaan proporsi menggunakan uji chi-square. Analisis bivariat faktor luar dengan mengikutsertakan variabel berat badan lahir, kadar hemoglobin, status ekonomi, pendidikan ibu dan stimulasi diuji dengan chi-square dan Fisher, Penelitian ini telah disetujui oleh Komite Etik dari 
Fakultas Kedokteran Universitas Gadjah Mada. Orang tua anak yang bersedia mengikuti penelitian telah menandatangani informed concern.

\section{Hasil}

Didapatkan 80 anak (40 dengan inteligensi tinggi dan 40 dengan inteligensi rendah) yang diikutkan dalam penelitian. Karakteristik subyek penelitian tertera pada Tabel 1

Rerata kadar timbal darah anak dengan tingkat inteligensi rendah $(7,08 \mu \mathrm{g} / \mathrm{dL}(0,61))$ lebih tinggi daripada anak dengan tingkat inteligensi tinggi $(4,09$ $\mu \mathrm{g} / \mathrm{dL}(0,50))(\mathrm{IK} 95 \% 1,429-4,555)$ seperti tertera pada Tabel 2.

Kadar timbal dalam darah $>5 \mu \mathrm{g} /$ dL lebih banyak dijumpai pada anak dengan inteligensi rendah dibandingkan anak dengan inteligensi tinggi $(75 \%$ vs 45\%), dengan analisis chi-square didapatkan $\mathrm{p}=0,006$ (Tabel 3).

Beberapa faktor lain yang berhubungan bermakna dengan tingkat inteligensi anak adalah status ekonomi, pendidikan ibu, dan stimulasi yang dinilai dengan skala HOME ( $\mathrm{p}=0,001, \mathrm{p}=0,001$, dan $\mathrm{p}<0,001$ (Tabel 4)

\section{Pembahasan}

Hasil penelitian membuktikan bahwa terdapat perbedaan kadar timbal pada anak dengan tingkat inteligensi tingi dan rendah. Proporsi anak dengan kadar timbal $>5 \mu \mathrm{g} / \mathrm{dL}$ lebih banyak pada anak dengan inteligensi rendah dibandingkan anak dengan

Tabel 1. Data karakteristik dasar subyek penelitian

\begin{tabular}{lcc}
\hline Karakteristik & & Total \\
\hline Umur (tahun) & Rerata \pm SB & $7,99 \pm 1,24$ \\
Jenis kelamin & $\mathrm{n}(\%)$ & $49(61,3)$ \\
$\quad$ Laki-laki & $\mathrm{n}(\%)$ & $31(38,7)$ \\
$\quad$ Perempuan & Rerata \pm SB & $3109 \pm 418,26$ \\
Berat badan lahir $(\mathrm{gram})$ & $\mathrm{n}(\%)$ & $0(0)$ \\
$\quad<2500$ & $\mathrm{n}(\%)$ & $100(100)$ \\
$\geq 2500$ & Rerata \pm SB & $12,62 \pm 0,75$ \\
Kadar hemoglobin $(\mathrm{gr} / \mathrm{dL})$ & $\mathrm{n}(\%)$ & $4(5)$ \\
$\quad$ Anemia & $\mathrm{n}(\%)$ & $76(95)$ \\
Tidak anemia & & \\
Status ekonomi & $\mathrm{n}(\%)$ & $32(40)$ \\
$\quad$ Rendah & $\mathrm{n}(\%)$ & $48(60)$ \\
Tinggi & $\mathrm{n}(\%)$ & $35(43,8)$ \\
Pendidikan Ibu & $\mathrm{n}(\%)$ & $45(55,9)$ \\
Tidak tamat SLTP & & \\
Tamat SLTP & $\mathrm{n}(\%)$ & $34(42,5)$ \\
Stimulasi (skala HOME) & $\mathrm{n}(\%)$ & $44(55)$ \\
$\quad$ Rendah & $\mathrm{n}(\%)$ & $2(2,5)$ \\
$\quad$ Menengah & & \\
Tinggi &
\end{tabular}

Tabel 2. Rerata kadar timbal darah anak dengan inteligensi tinggi dan rendah

\begin{tabular}{lccc}
\hline Faktor & $\begin{array}{c}\text { Rerata kadar timbal dalam darah } \mu \mathrm{g} / \\
\mathrm{dL}( \pm \mathrm{SB})\end{array}$ & $\mathrm{p}$ & $\mathrm{IK} 95 \%$ \\
\hline Inteligensi rendah & $7,08_{ \pm} 0,61$ & \multirow{2}{*}{0,000} & $1,425-4,555$ \\
Inteligensi tinggi & $4,09 \pm 0,50$ & & \\
\hline
\end{tabular}

Uji independent t-test bermakna secara statistik jika $\mathrm{p}<0,05$ 
Dewi Mutiati Ratnasari dkk: Hubungan kadar timbal darah dengan tingkat inteligensi anak

Tabel 3. Proporsi kadar timbal darah pada anak dengan ineligensi tinggi dan rendah

\begin{tabular}{lccc}
\hline Faktor & Tingkat inteligensi tinggi & Tingkat inteligensi rendah & $\mathrm{p}$ \\
\hline & $\mathrm{n}(\%)$ & $\mathrm{n}(\%)$ & \\
\hline Proporsi kadar $\mathrm{Pb}<5 \mu \mathrm{g} / \mathrm{dL}$ & $22(55)$ & $10(25)$ & $0,006^{*}$ \\
Proporsi kadar $\mathrm{Pb} \geq 5 \mu \mathrm{g} / \mathrm{dL}$ & $18(45)$ & $30(75)$ & \\
\hline
\end{tabular}

Keterangan :*uji chi-square, bermakna secara statistik jika $\mathrm{p}<0,05$

Tabel 4. Analisis bivariat faktor luar dengan inteligensi anak

\begin{tabular}{|c|c|c|c|c|}
\hline Karakteristik & & $\begin{array}{l}\text { Inteligensi tinggi } \\
\mathrm{n}=40\end{array}$ & $\begin{array}{l}\text { Inteligensi rendah } \\
\mathrm{n}=40\end{array}$ & $\mathrm{p}$ \\
\hline Berat badan lahir (\%, gram) & Rerata $\pm S B$ & $3191 \pm 321$ & $3027 \pm 487$ & \\
\hline$<2500$ & & $0(0)$ & $0(0)$ & \\
\hline$\geq 2500$ & & $100(100)$ & $100(100)$ & \\
\hline Kadar hemoglobin (\%) & Rerata $\pm S B$ & $12,69 \pm 0,77$ & $12,54 \pm 0,74$ & \\
\hline Anemia & & $3(7,5)$ & $1(2,5)$ & $0,615^{*}$ \\
\hline Tidak anemia & & $37(92,5)$ & $39(97,5)$ & \\
\hline \multicolumn{5}{|l|}{ Status ekonomi (\%) } \\
\hline Rendah & & $9(22,5)$ & $23(57,5)$ & $0,001^{* *}$ \\
\hline Tinggi & & $31(77,5)$ & $17(42,5)$ & \\
\hline \multicolumn{5}{|l|}{ Pendidikan ibu (\%) } \\
\hline Tidak tamat SLTP & & $10(25)$ & $25(62,5)$ & $0,001^{* *}$ \\
\hline Tamat SLTP & & $30(75)$ & $15(37,5)$ & \\
\hline \multicolumn{5}{|l|}{ Stimulasi (\%) } \\
\hline Rendah & & $6(15)$ & $28(70)$ & $<0,001^{* *}$ \\
\hline Tinggi & & $34(85)$ & $12(30)$ & \\
\hline
\end{tabular}

Keterangan :*uji fisher, bermakna secara statistik jika $\mathrm{p}<0,05,{ }^{* *}$ uji chi- square, bermakna secara statistik jika $\mathrm{p}<0,05$

inteligensi tinggi. Hal ini sesuai dengan penelitian yang dilakukan oleh Rochester longitudinal study yang membandingkan tingkat inteligensi anak pada kadar timbal kurang dari $5 \mu \mathrm{g} / \mathrm{dL}$ dengan kadar 5-10 $\mu \mathrm{g} /$ dL. Pada penelitian longitudinal tersebut dilaporkan bahwa tingkat inteligensi anak turun 4,9 point lebih rendah pada anak dengan timbal $5-10 \mu \mathrm{g} / \mathrm{dL} .^{7}$ Pengaruh timbal terhadap inteligensi dapat melalui gangguan sintesis heme dengan menghambat enzim delta aminolevulinic acid dehydratase dan kompetitor terhadap kerja kalsium yang menyebabkan apoptosis sel, gangguan neurotransmitter dan menghambat diferensiasi progenitor glia. ${ }^{13}$

Saat ini, kadar timbal darah yang dianggap dapat ditoleransi pada anak adalah $10 \mu \mathrm{g} / \mathrm{dL}$. Berdasarkan beberapa hasil penelitian yang melaporkan dampak paparan timbal, walaupun kadar timbal rendah, maka saat ini CDC merencanakan menurunkan batas ambang kadar timbal serum menjadi $5 \mu \mathrm{g} / \mathrm{dL} .{ }^{23}$ Jika batas keamanaan timbal menjadi $5 \mu \mathrm{g} / \mathrm{dL}$ maka 15 anak
(45\%) dengan tingkat inteligensi tinggi dan 30 anak (75\%) dengan tingkat inteligensi rendah maka orang tua harus mendapat edukasi mengenai bahaya timbal di lingkungannya, mencari tahu sumber paparan, memonitor kadar timbal dalam darah setiap 3 bulan, dan penyuluhan aktivitas masyarakat untuk melakukan pencegahan terhadap paparan timbal yang tinggi. ${ }^{16}$ Tahun 2006, the scientific committee on neurotoxicity and psychophysiology and the scientific committee on occupational health juga merekomendasikan program pemerintah untuk meminimalkan paparan timbal jika kadar timbal dalam darah anak $\geq 5 \mu \mathrm{g} / \mathrm{dL} .{ }^{24}$

Kadar timbal dalam darah lebih rendah dibandingkan penelitian yang pernah dilakukan di Jakarta yang menemukan rerata kadar timbal dalam darah 8,6 $\mu \mathrm{g} / \mathrm{dL}$. Di antara 400 anak sekolah dasar, 35\% anak mempunyai kadar timbal dalam darah $>10 \mu \mathrm{g} /$ dL dan 2,4\% mempunyai kadar timbal dalam darah $>20 \mu \mathrm{g} / \mathrm{dL} .{ }^{15}$ Penelitian lain melaporkan rerata kadar timbal dalam darah 9,4 $\mu \mathrm{g} / \mathrm{dL}$ pada anak usia 7-9 tahun 
dengan penurunan inteligensi 6,9 poin pada kenaikan kadar timbal dari 2,4 $\mu \mathrm{g} / \mathrm{dL}$ menjadi $30 \mu \mathrm{g} / \mathrm{dL}^{7}$

Nilai rerata kadar timbal dalam darah yang rendah dapat disebabkan beberapa hal, yaitu penelitian dilakukan saat paparan timbal pada bensin belum dihapuskan atau paparan timbal terhadap anak di lingkungan penelitian yang mungkin memang rendah. Untuk mengetahui penyebab tersebut perlu diukur kadar timbal udara, air, tanah, maupun mainan anakanak yang sering digunakan pada lingkungan tersebut. Hal ini merupakan keterbatasan pada penelitian ini.

Pada batas timbal $5 \mathrm{mg} / \mathrm{dL}$ ditemukan perbedaan antara kadar timbal dengan inteligensi anak. Disimpulkan bahwa anak dengan inteligensi tinggi memiliki kadar timbal rendah $(\leq 5 \mathrm{mg} / \mathrm{dL})$ secara bermakna dibandingkan anak dengan inteligensi rendah. Disarankan perlu dilakukan penelitian lebih lanjut mengenai hubungan kadar timbal darah dan tingkat inteligensi anak dengan metode kohort prospektif

\section{Daftar pustaka}

1. Azwar S. Pengantar Psikologi Inteligensi. Edisi pertama. Yogyakarta: Pustaka Pelajar; 1996.

2. Gravitiani E. Lead Pollution Causes 29,234 Cases of IQ Decrease in Children. Universitas Gadjah Mada. Didapat dari: http://ugm.ac.id/en/news/5131-lead.pollution.causes.29234.cases. of.iq.decrease.in.children

3. World Health Organization. Exposure to lead: a major public health concern. Geneva: World Health Organization; 2010.

4. Canfield RL, Henderson CR, Deborah A. Intellectual impairment in children with blood lead concentrations, $\mathrm{N}$ Engl J Med 2003;348:1517-26.

5. Lanphear BP, Dietrich MP, Auinger P, Cox MSC. Cognitive deficits associated with blood lead concentration $<10$ microg/dL in US children and adolescents. Pub Health Rep 2000;115:521-9.

6. Jakubowski, M. Low level environmental lead exposure and intellectual impairement in children - the current concepts of risk assessment. International Journal of Occipational Med and Environ Health 2011;24:1-7.

7. Jusko TA, Henderson CR, Lanphear BP, Slechta CD, Parsons PJ, Canfield RL. Blood lead concentrations $<10$ microg/dL and child intelligence at 6 years of age. Environ Health Pers 2008;116:243-8.

8. Mazumdar M, Bellinger DC, Gregas M, Abanilla K, Bacic
J, Needleman HL. Low level environmental lead exposure in childhood and adult intellectual function: a follow up study. Environ Health 2011;10:1-8

9. Prussustun A, Fewtrell L, Landrigan PJ, Ayusomateos JL. Lead exposure. Dalam: Comparative Quantification of Health Risks. World Health Organization 2003;19:1495-1530.

10. Qamariah N. Mainan Cina di RI mengandung timbal $4 x$ lipat di atas normal. Detik [online] Agust 2007 [cited 30 Juli 2012]. Didapat dari: URL: http://us.detikfinance.com/index.php/detik. read/tahun/2007/bulan/08/tgl/22/time/122950/idnews/820209/ idkanal/4

11. Agency for Toxic Substances and Disease Registry. Toxicological profile for lead. Atlanta, GA: US Department of Health and Human Services, Public Health Service, Agency for Toxic Substance and Disease Registry;2007

12. Palar H. Pencemaran dan toksikologi logam berat. Edisi pertama. Jakarta: Rineka Cipta;2008.

13. Lidsky TI, Schneider JS. Lead neurotoxicity in children: basic mechanisms and clinical correlates. Brain 2003;126:5-19.

14. Patrick L. Lead toxicity a review of the literature part I: exposure, evaluation, and treatment. Altern Med Rev 2006;11:2-22.

15. Albalak R, Noonan G, Buchanan S. Blood lead levels and risk factors for lead poisoning among children in Jakarta, Indonesia. The Science of Total Environ 2003;301:75-85.

16. Landrigan PJ, Kellner CH. CDC updates guidelines for children's lead exposure. Environ Health Pers 2012;120:268.

17. Azwar S. Penyusunan skala psikologi. Edisi kedua. Yogyakarta: Pustaka Pelajar; 2012.

18. Lanzkowsky P. Manual of pediatric hematology and oncology. Edisi ke-4. USA: Elsevier Academic Press; 2005.

19. WHO. Low birth weight country regional and global estimates. United Nations Childrens and World Health Organization. New York: WHO; 2004.

20. Caldwell B, Bradley R. Home Observation For Measurement of The Environment. University of Arkansas, 1984.

21. Menteri Pendidikan Nasional Republik Indonesia. Peraturan Menteri Pendidikan Nasional Republik Indonesia Nomor 35 tahun 2006. Didapat dari: http://ftp.unm.ac.idl permendiknas-2006/Nomor 35 Tahun 2006.pdf.

22. Dinas Tenaga Kerja dan Transmigrasi. 2012. Upah minimum regional. Didapat dari: http://www.nakertrans.jogjaprov.go.id.

23. Center for Disease Control and Prevention. Preventing lead poisoning in young children. Atlanta: CDC; 2005.

24. Landrigan P, Nordberg M, Luccini R, Nordberg. The declaration of brescia on prevention of the neurotoxicity of metals. Am J Ind Med 2006;50:709-11. 